Original Research Paper

\title{
Optimalisasi Pusat Kegiatan Belajar Masyarakat (PKBM) Jero Juangga dalam Rangka Peningkatan Kualitas Pendidikan di Dusun Penyonggok Desa Tetebatu Selatan
}

\author{
Ni Nyoman Sri Putu Verawati ${ }^{*}$, Maya Indriani ${ }^{2}$, Hikmawati, Hikmawati ${ }^{1}$ \\ ${ }^{I}$ Program Studi Pendidikan Fisika, Fakultas Keguruan dan Ilmu Pendidikan, Universitas Mataram, Mataram, Indonesia \\ ${ }^{2}$ Program Studi Pendidikan Kimia, Fakultas Keguruan dan Ilmu Pendidikan, Universitas Mataram, Mataram, Indonesia.
}

DOI: https://doi.org/10.29303/jpmpi.v4i2.707

Sitasi: Verawati, N. N. S. P., Indriani, M., \& Hikmawati, H. (2021). Optimalisasi Pusat Kegiatan Belajar Masyarakat (PKBM) Jero Juangga dalam Rangka Peningkatan Kualitas Pendidikan di Dusun Penyonggok Desa Tetebatu Selatan. Jurnal Pengabdian Magister Pendidikan IPA, 4(2)

\section{Article history}

Received: 03 Februari 2021

Revised: 08 Maret 2021

Accepted: 26 April 2021

*Corresponding Author: Ni Nyoman Sri Putu Verawati, Program Studi Pendidikan Fisika, Fakultas Keguruan dan Ilmu Pendidikan, Universitas Mataram, Mataram, Indonesia; Email: veyra@unram.ac.id

\begin{abstract}
Kegiatan optimalisasi pusat kegiatan belajar masyarakat (PKBM) merupakan salah satu program kerja kegiatan KKN terpadu era New Normal, Kegiatan ini bertempat di PKBM Jero Juangga Dusun Penyonggok Desa Tetebatu Selatan. PKBM Jero Juangga merupakan salah satu PKBM yang digagaskan oleh sekelompok pemuda-pemudi Jero Juangga Dusun Penyonggok Desa Tetebatu Selatan dalam rangka membantu dan memfasilitasi anak-anak dalam belajar khususnya yang masih sekolah selama masa pandemi Covid-19. Tujuan dari kegiatan ini yaitu melakukan pendampingan dalam rangka optimalisasi pusat kegiatan belajar masyarakat (PKBM) yang meliputi: pembuatan perangkat pembelajaran, mengajar di PKBM, pendampingan kegiatan tambahan di PKBM dan edukasi hidup bersih dan sehat. Sasaran dari kegiatan ini yaitu peserta didik yang telah tergabung di PKBM Jero Juangga. Alur dari kegiatan ini yaitu permohonan izin kepada Kepala Desa, Kepala Wilayah, dan pengurus PKBM Jero Juangga, observasi PKBM Jero Juangga, pendataan peserta didik dan sosialisasi, penyusunan perencanaan dan perangkat pembelajaran, persiapan tempat belajar yang memadai, kegiatan pembelajaran di PKBM Jero Juangga dan evaluasi kegiatan pembelajaran. Pelaksanaan kegiatan optimalisasi PKBM Jero Juangga berjalan lancar dan mendapatkan dukungan yang penuh dari pengurus PKBM maupun masyarakat sekitar.
\end{abstract}

Keywords: PKBM Jero Juangga; Pendidikan; Tete Batu Selatan.

\section{Pendahuluan}

Pendidikan di Indonesia terbagi ke dalam tiga jalur utama, yaitu formal, nonformal, dan informal. Pendidikan juga dibagi ke dalam empat jenjang, yaitu anak usia dini, dasar, menengah, dan tinggi (Sunarsi, 2018). Menurut Hatimah (2006) pendidikan memiliki fungsi sebagai lembaga yang melakukan pelestarian nilai sosial budaya. Dalam setiap masyarakat ditemukan sistem belajar asli (indigenous) yang memiliki ketangguhan dan ketahanan dalam memelihara keseimbangan kehidupan sosial. Melalui konsep pendidikan berbasis masyarakat, program-program pendidikan luar sekolah diharapkan dapat menyesuaikan dan memanfaatkan perkembangan teknologi serta disesuaikan dengan kondisi lingkungan sosial budaya masyarakat. 
Pendidikan luar sekolah berfungsi mengembangkan potensi peserta didik atau warga belajar dengan penekanan pada penguasaan pengetahuan dan keterampilan fungsional serta pengembangan sikap dan kepribadian profesional (Putra et al., 2017). Kelembagaan pendidikan luar sekolah dikelola oleh, dari, dan untuk masyarakat serta merupakan milik masyarakat, diwujudkan dalam Pusat Kegiatan Belajar Masyarakat (PKBM).

Pusat Kegiatan Belajar Masyarakat (PKBM) merupakan pusat pembelajaran masyarakat yang ada di sekitar kehidupan masyarakat. PKBM dapat menjadi penyelenggara utama program pendidikan yang mampu secara sungguh menjawab kebutuhan masyarakat. Hal ini dapat dipastikan sebab proses pembelajaran yang diselenggarakan oleh PKBM adalah program pembelajaran yang menyenangkan (Pamungkas et al., 2018). Program pembelajaran demikian dapat memenuhi kebutuhan belajar yang beragam. Hal ini terjadi karena sifat program layanan PLS berbasis pada kemauan dan kebutuhan warga belajar.

PKBM Jero Juangga adalah salah satu PKBM yang digagaskan oleh sekelompok pemudapemudi Jero Juangga Dusun Penyonggok Desa Tetebatu Selatan dalam rangka membantu dan memfasilitasi anak-anak dalam belajar khususnya yang masih sekolah selama masa pandemi Covid19. Sebagaimana diketahui selama masa pandemi sekolah diliburkan dan kegiatan pembelajaran beralih menjadi daring. Banyak peserta didik di Dusun Penyonggok yang mengalami kesulitan selama mengikuti proses pembelajaran daring, mulai dari pemahaman materi dan fasilitas yang tidak memadai, sehingga terbentuklah PKBM Jero Juangga.

Di PKBM Jero Juangga diajarkan mata pelajaran Bahasa Inggris, Matematika, dan Bahasa Arab dengan jumlah guru sebanyak tiga orang. Dimana hanya satu guru yang memiliki latar belakang pendidikan guru, satu guru dengan latar belakang pendidikan pariwisata, dan satu guru lainnya masih berstatus mahasiswa pendidikan fisika. PKBM Jero Juangga hanya memiliki satu tempat belajar berupa berugak yang digunakan secara bergiliran oleh masing-masing kelompok belajar (kelompok A, B, dan C).

Dalam mengelola pembelajaran di PKBM, tidak terlepas dari permasalahan yang dihadapi yaitu: (1) kekurangan tenaga pengajar, (2) dalam kegiatan pembelajaran di PKBM hanya disampaikan secara dadakan tanpa perencanaan yang semestinya seperti pembuatan silabus, RPP, modul dan sebagainya, (3) materi pembelajaran yang diajarkan terbatas sehingga berdampak pada ketidakberlanjutan program, karena kurangnya tenaga pengajar yang ahli pada bidang mata pelajaran yang dibutuhkan oleh peserta didik. Oleh karena itu, perlu dilakukan kegiatan tentang optimalisasi Pusat Kegiatan Belajar Masyarakat (PKBM) Jero Juangga dalam rangka peningkatan kualitas pendidikan di Dusun Penyonggok Desa Tetebatu Selatan.

\section{Metode}

Kegiatan optimalisasi PKBM merupakan salah satu program kerja KKN Terpadu Era New Normal bertempat di Pusat Kegiatan Belajar Masyarakat (PKBM) Jero Juangga Dusun Penyonggok Desa Tetebatu Selatan. Kegiatan ini dilakukan selama 45 hari atau 6 pekan terhitung dari tanggal 23 November 2020 sampai dengan tanggal 7 Januari 2021. Sasaran dari kegiatan ini yaitu peserta didik yang telah tergabung di Pusat Kegiatan Belajar Masyarakat (PKBM) Jero Juangga. Peserta didik terdiri dari anak-anak yang masih menempuh pendidikan di sekolah yang tergabung dalam 3 kelompok, yaitu kelompok A (anak-anak PAUD dan TK), kelompok B (anakanak Sekolah Dasar), dan kelompok C (anak-anak Sekolah Menengah Pertama atau SMP). Total jumlah peserta didik yang aktif mengikuti kegiatan belajar mengajar di PKBM Jero Juangga adalah 62 orang.

Desain kegiatan ini dapat dikategorikan sebagai pendampingan karena kegiatan yang dilakukan berupaya untuk mengoptimalkan Pusat Kegiatan Belajar Masyarakat (PKBM) Jero Juangga dalam rangka peningkatan kualitas pendidikan di Dusun Penyonggok Desa Tetebatu Selatan. Adapun alur dari kegiatan ini yaitu sebagai berikut.

Permohonan Izin kepada Kepala Desa, Kepala Wilayah, dan Pengurus PKBM Jero Juangga

Permohonan izin dilakukan guna mendapatkan persetujuan dari Kepala Desa dan Kepala Wilayah setempat serta dapat bekerja sama dengan pihak Pusat Kegiatan Belajar Masyarakat (PKBM) Jero Juangga. 


\section{Observasi PKBM Jero Juangga}

Observasi dilakukan agar mengetahui bagaimana kondisi dari PKBM Jero Juangga meliputi jumlah tenaga pengajar, mata pelajaran yang diprogramkan, organisasi kepengurusan PKBM, sarana dan prasarana PKBM, jadwal pembelajaran, jumlah peserta didik, dan kegiatan PKBM di luar proses pembelajaran.

\section{Pendataan Peserta Didik dan Sosialisasi}

Pendataan dan sosialisasi dilakukan karena banyak peserta didik yang sering tidak hadir selama proses pembelajaran karena terbatasnya materi yang diajarkan dan kegiatan yang kurang bervariatif serta inovatif.

Penyusunan Perencanaan dan Perangkat Pembelajaran

Permendikbud No. 65 Tahun 2013 tentang Standar Proses Pendidikan Dasar dan Menengah menyebutkan bahwa proses pembelajaran pada satuan pendidikan diselenggarakan secara interaktif, inspiratif, menyenangkan, menantang, memotivasi peserta didik untuk berpartisipasi aktif, serta memberikan ruang yang cukup bagi prakarsa, kreativitas dan kemandirian sesuai dengan bakat, minat dan perkembangan fisik serta psikologis peserta didik. Untuk itu setiap satuan pendidikan perlu melakukan perencanaan pembelajaran, pelaksanaan proses pembelajaran serta penilaian proses pembelajaran untuk meningkatkan efisiensi dan efektivitas ketercapaian kompetensi lulusan. Guna mencapai hal tersebut, maka proses pembelajaran perlu direncanakan dengan baik dan didukung oleh perangkat pembelajaran yang valid, praktis dan efektif (Nieveen, 1999).

Penyusunan perencanaan dan perangkat pembelajaran dilakukan agar program yang ada di PKBM tetap terlaksana dan berjalan lancar. Perangkat pembelajaran merupakan bahan utama dalam mencapai kesuksesan pembelajaran dan mencipta pembelajaran yang interaktif, inspiratif, menyenangkan, menantang, efisien, memotivasi siswa untuk berpartisipasi aktif, serta memberikan ruang yang cukup bagi prakarsa, kreativitas, dan kemandirian sesuai dengan bakat, minat, dan perkembangan fisik serta psikologis siswa (Susanto et al., 2016). Perangkat pembelajaran yang disusun berupa silabus, RPP, modul, dan instrumen penilaian.

\section{Persiapan Tempat Belajar yang Memadai}

Persiapan ini dilakukan agar peserta didik lebih nyaman saat mengikuti proses pembelajaran. Persiapan meliputi penyediaan peralatan mengajar, penyediaan tempat cuci tangan sesuai protokol kesehatan, dan penyediaan spanduk yang berisi tentang kegiatan PKBM Jero Juangga.

\section{Kegiatan Pembelajaran di PKBM Jero Juangga}

Pembelajaran adalah kegiatan yang didalamnya terkandung dua unsur pokok, yaitu unsur kegiatan guru dan siswa (Nadzir, 2013). Kegiatan pembelajaran di PKBM jero Juangga dilakukan dari hari senin hingga sabtu dengan mata pelajaran matematika, bahasa Inggris, bahasa Arab, menggambar dan mewarnai, membaca dan menulis, serta bina islam. Sedangkan hari minggu dilakukan kegiatan olahraga bersama, membersihkan lingkungan, dan pembuatan kerajinan dari barang bekas.

Evaluasi Kegiatan Pembelajaran di PKBM Jero Juangga

Evaluasi dilakukan untuk mengetahui sejauh mana keberhasilan program PKBM Jero Juangga berhasil dilaksanakan.

\section{Hasil dan Pembahasan}

Kegiatan pengoptimalan PKBM Jero Juangga di Dusun Penyonggok Desa Tetebatu Selatan terlaksana pada tanggal 23 November 2020 - 7 Januari 2021. Kegiatan ini diawali dengan pendataan ulang peserta didik dan sosialisasi. Kegiatan ini bertujuan untuk mendata ulang peserta didik yang mengikuti kegiatan belajar di PKBM Jero Juangga, karena beberapa dari peserta didik sering kali tidak hadir selama kegiatan pembelajaran.

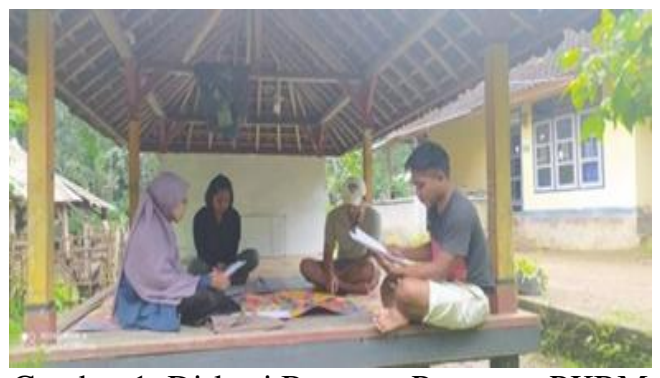

Gambar 1. Diskusi Bersama Pengurus PKBM 
Berdasarkan hasil observasi dan diskusi bersama pengurus di PKBM Jero Juangga, diperoleh data kehadiran peserta didik yang mengalami penurunan dari bulan sebelumnya. Pendataan ulang dilakukan dengan mendatangi rumah masing-masing peserta didik. Setelah dilakukan pendataan jumlah peserta didik yaitu 62 orang, terdiri dari kelas A (kelompok PAUD dan TK) sebanyak 6 orang, kelas B (kelompok SD) sebanyak 38 orang, dan kelas C (kelompok SMP) sebanyak 18 orang.

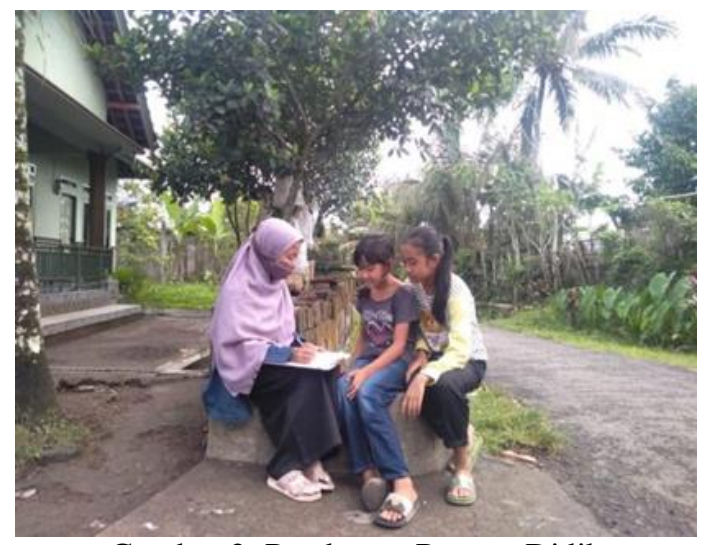

Gambar 2. Pendataan Peserta Didik

Bersamaan dengan kegiatan ini, dilakukan sosialisasi kepada orang tua peserta didik. Mengingat banyaknya peserta didik sosialisasi dilakukan dengan mengunjungi setiap rumah peserta didik karena selama masa pandemi Covid19 masyarakat dilarang berkumpul di satu tempat. Sosialisasi bertujuan untuk menginformasikan kepada peserta didik dan orang tuanya tentang manfaat mengikuti kegiatan pembelajaran di PKBM, kelas yang bisa diikuti peserta didik, dan jadwal kegiatan PKBM.

Orang tua peserta didik memberikan respon yang baik serta dukungan terhadap kegiatan PKBM yang akan diikuti oleh anak-anak. Orang tua senang karena anak-anak mereka mendapatkan bimbingan belajar karena di rumah anak-anak jarang belajar dan lebih sering bermain gadget. Sedangkan di sekolah anak-anak tidak maksimal dalam menerima pembelajaran dari guru akibat belajar secara online. Orang tua berharap dengan adanya kegiatan PKBM ini dapat membantu anak-anak dalam belajar.

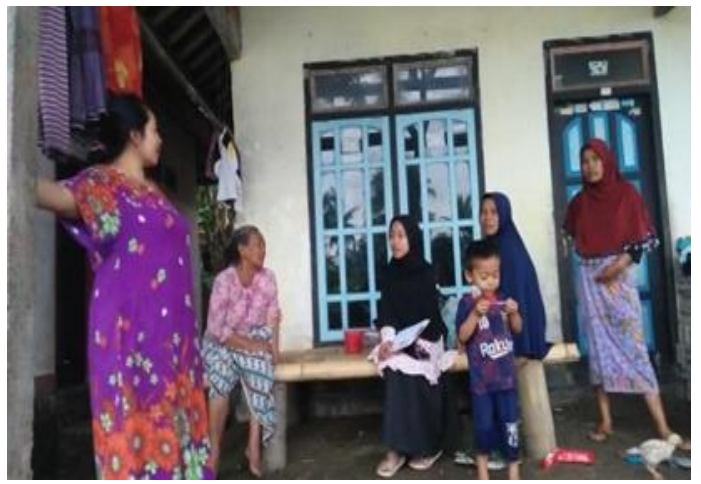

Gambar 3. Sosialisasi Kepada Orang Tua Peserta Didik

Salah satu permasalahan yang dihadapi PKBM Jero Juangga dalam kegiatan pembelajaran yaitu materi pelajaran terbatas karena hanya disampaikan secara dadakan tanpa perencanaan yang semestinya seperti pembuatan silabus, RPP, modul dan sebagainya. Sehingga pembuatan perangkat pembelajaran dirasa perlu untuk dilakukan. Pembuatan perangkat pembelajaran dilaksanakan pada minggu pertama kegiatan bersama dengan pengurus PKBM yaitu sekertaris dan guru di PKBM Jero Juangga. Adapun perangkat pembelajaran yang dibuat yaitu daftar hadir, silabus, RPP, modul pembelajaran, dan instrumen penilaian dari masing-masing mata pelajaran yang akan diajarkan.

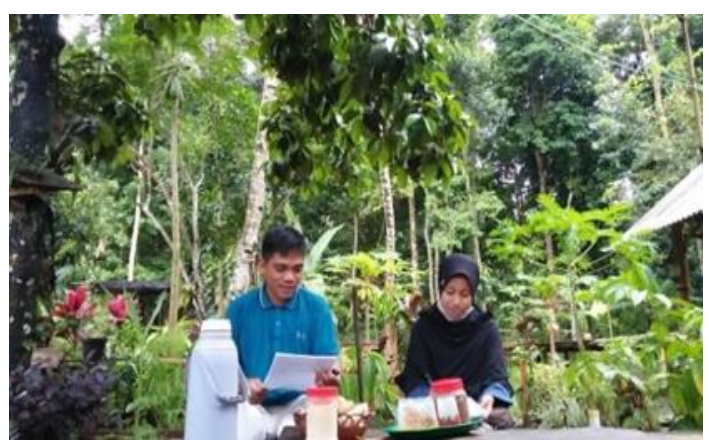

Gambar 4. Penyusunan Perangkat Pembelajaran PKBM

Dari segi sarana dan prasarana, PKBM Jero Juangga sebelumnya hanya memiliki satu kelas berupa berugak yang dilengkapi dengan peralatan belajar mengajar. Keterbatasan tempat dan cuaca yang sering hujan membuat proses pembelajaran kurang efektif. Sehingga harus disiapkan tempat belajar yang mendukung saat cuaca sedang hujan. Sekarang PKBM memiliki tiga ruang kelas dimana terdiri dari dua berugak dan satu kelas dalam 
ruangan (rumah warga setempat yang tidak digunakan pemiliknya).

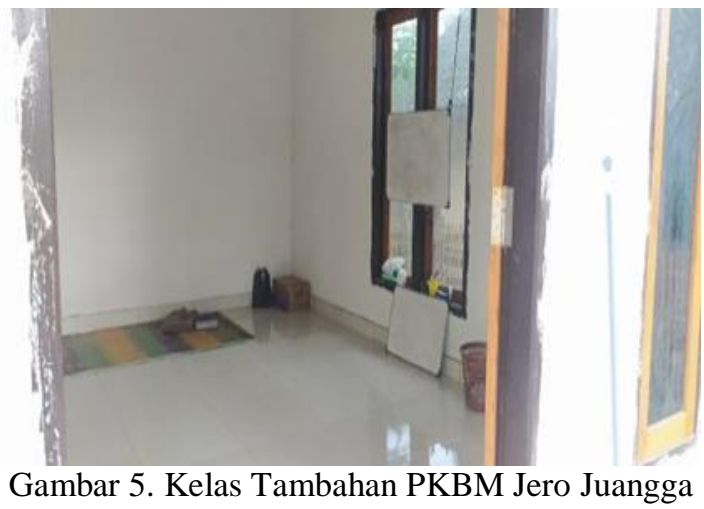

Persiapan ini dilakukan agar peserta didik lebih nyaman saat mengikuti proses pembelajaran. Selain itu dilakukan penyediaan peralatan mengajar, penyediaan tempat cuci tangan sesuai protokol kesehatan, penyediaan spanduk yang berisi tentang kegiatan PKBM Jero Juangga, dan penempelan poster-poster seputar mata pelajaran di kelas.

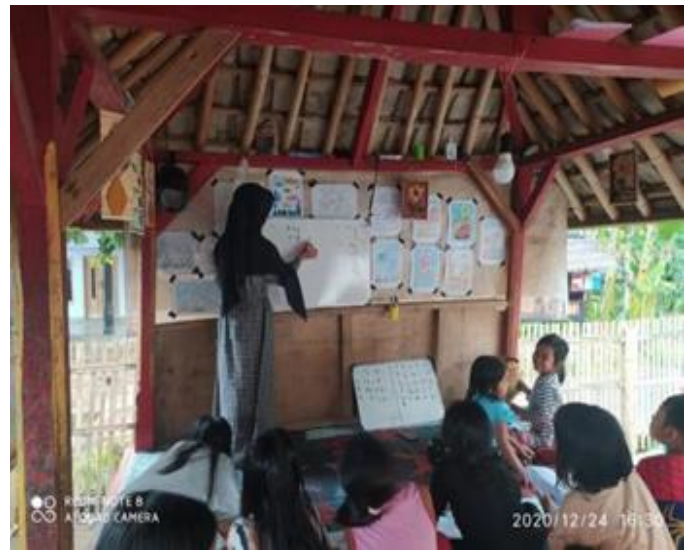

Gambar 6. Kegiatan Belajar PKBM Jero Juangga

Setelah perangkat pembelajaran dan kelas telah selesai disiapkan kemudian dilaksanakan kegiatan belajar mengajar. Kegiatan ini dilaksanakan mulai pada minggu kedua. PKBM Jero Juangga memiliki tiga guru, yaitu guru bahasa Arab, guru bahasa Inggris, serta guru yang mengajar membaca, menulis, dan berhitung. Dari ketiga guru tersebut hanya satu guru yang memiliki latar belakang sebagai tenaga pengajar. Keterbatasan guru juga merupakan masalah yang dihadapi PKBM, sehingga diperlukan tenaga pengajar untuk mata pelajaran matematika.

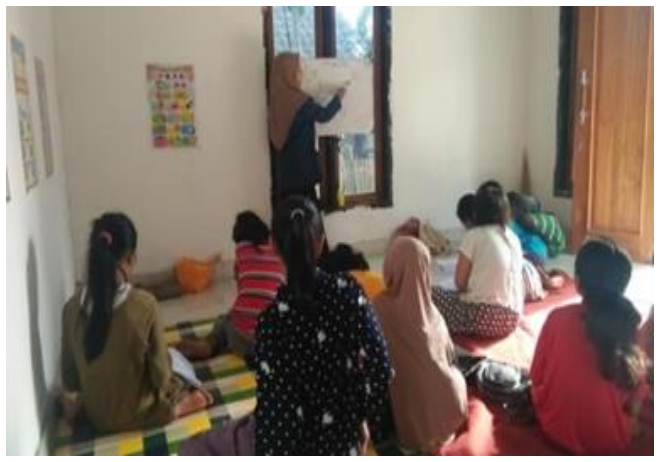

Gambar 7. Kegiatan Belajar Matematika

Belajar matematika dijadwalkan empat kali dalam satu minggu, yaitu hari senin, selasa, kamis, dan sabtu. Sedangkan bahasa Arab hari jum'at dan bahasa Inggris hari rabu. Materi yang diajarkan disesuaikan dengan jenjang sekolah. Peserta didik dikelompokkan berdasarkan jenjang sekolah sehingga peserta didik mendapatkan materi pelajaran sesuai dengan kebutuhannya.

Selain kegiatan pembelajaran juga dilaksanakan kegiatan tambahan yang diharapkan mampu mengembangkan sikap dan keterampilan peserta didik. Kegiatan tambahan di PKBM Jero Juangga terdiri dari membersihkan lingkungan, membuat kerajinan, olahraga bersama dan bina islam (mengaji serta menghafal ayat-ayat pendek).

Membersihkan lingkungan sekitar PKBM dimaksudkan untuk mengajak peserta didik peduli terhadap kebersihan lingkungan. Kegiatan ini dilakukan setiap hari minggu di jalan-jalan dan selokan dusun Penyonggok desa Tetebatu Selatan. Kegiatan ini mendapatkan dukungan dari masyarakat setempat sehingga masyarakat ikut membantu kegiatan membersihkan lingkungan.

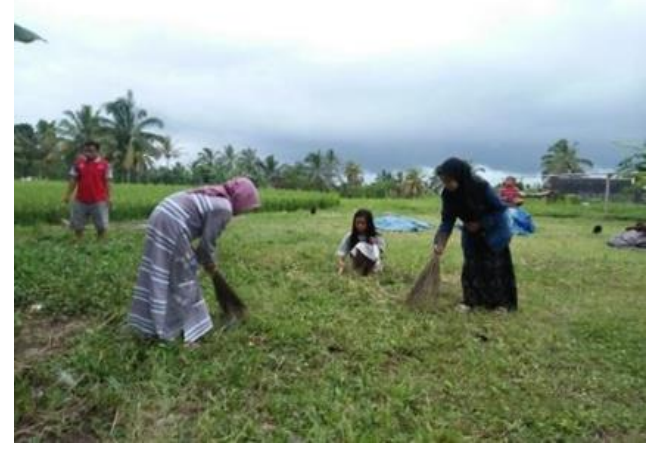

Gambar 8. Membersihkan Lingkungan

Untuk mengembangkan keterampilan peserta didik dan memanfaatkan barang bekas, pengurus PKBM dan pelaksana kegiatan KKN mengajak 
peserta didik membuat kerajinan berupa gantungan kunci, wadah penyimpanan, kotak pensil, dan hiasan dinding. Peserta didik sangat antusias mengikuti kegiatan ini. Hasil kerajinan peserta didik yaitu hiasan dinding tidak hanya dapat menjadi hiasan di kelas PKBM tetapi memiliki nilai jual.

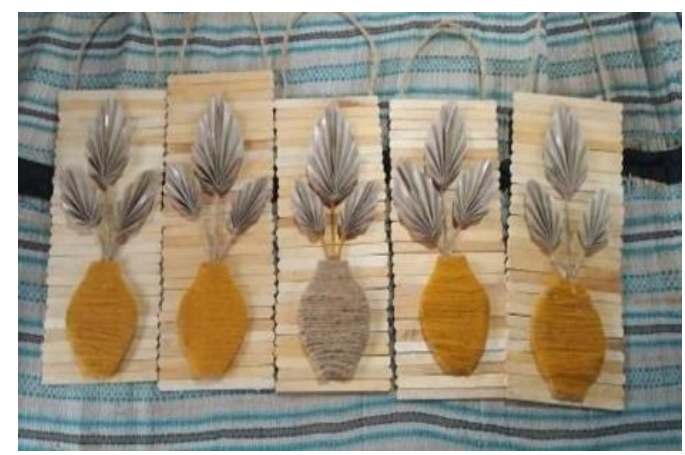

Gambar 9. Hiasan Dinding Karya Peserta Didik

Peserta didik biasanya tidak memiliki aktivitas di hari minggu pagi sehingga untuk memanfaatkan waktu peserta didik diajak untuk olahraga bersama. Kegiatan ini bertujuan untuk mengedukasi peserta didik bagaimana pentingnya menjaga kesehatan. Olahraga yang dilakukan terdiri dari senam sehat ceria dan lari pagi. Kegiatan ini dilakukan di halaman PKBM Jero Juangga.

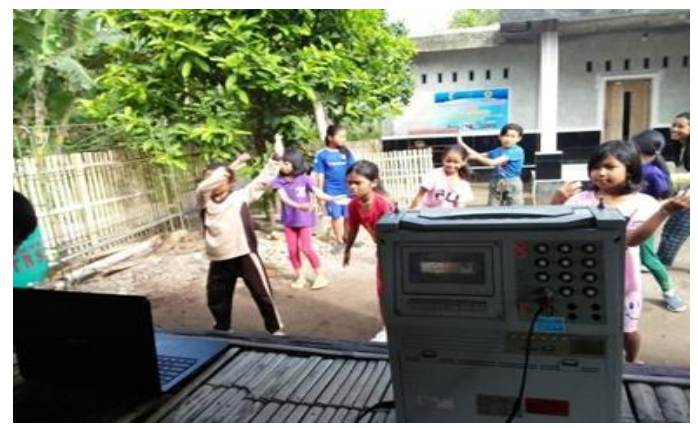

Gambar 10. Senam Sehat Ceria

Selain dilaksanakan kegiatan diatas, juga dilaksanakan edukasi hidup bersih dan sehat kepada peserta didik melalui kebiasaan 3M mencuci tangan dengan sabun, menjaga jarak dan menjauhi kerumunan, untuk mewujudkan hal tersebut, setiap kelas PKBM dilengkapi dengan tempat mencuci tangan sesuai dengan anjuran pemerintah tentang penerapan protokol kesehatan. Setiap peserta didik diwajibkan untuk mencuci tangan sebelum memasuki kelas dan ikut kegiatan belajar mengajar.

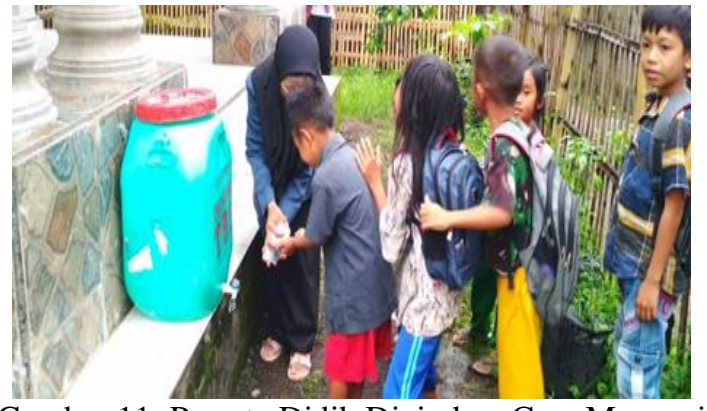

Gambar 11. Peserta Didik Diajarkan Cara Mencuci Tangan

\section{Kesimpulan}

Pelaksanaan Kegiatan Optimalisasi PKBM Jero Juangga yang merupakan bagian dari Program kerja KKN Era New Normal berjalan dengan lancar dan mendapatkan dukungan yang penuh dari pengurus PKBM maupun masyarakat sekitar. Tujuan kegiatan yang telah dilaksanakan yaitu pembuatan perangkat pembelajaran, mengajar di PKBM, pendampingan kegiatan tambahan PKBM Jero Juangga, serta edukasi hidup bersih dan sehat berhasil diselesaikan dengan baik bersama pengurus PKBM sesuai dengan waktu yang telah ditentukan. Perlu dilaksanakan kegiatan seperti ini secara berkelanjutan dalam rangka peningkatan kualitas pendidikan yang dimulai dari desa-desa terpencil.

\section{Daftar Pustaka}

Hatimah, Ihat. 2006. Pengelolaan Pembelajaran Berbasis Potensi Lokal di PKBM. Mimbar Pendidikan. Vol. 1(25): 39-45.

Nadzir, M. 2013. Perencanaan Pembelajaran Berbasis Karakter. Jurnal Pendidikan Agama Islam. Vol. 2(2): 339-352.

Nieveen, N., Gustafson, K., Branch, R. M., \& van den Akker, J. 1999. Design approaches and tools in education and training. Dordrecht: ICO Cluwer academic publisher.

Pamungkas, A. H. Sunarti, V. Wahyudi, W. A. 2018. PKBM dalam Peningkatan Pertumbuhan Ekonomi dan Kesejahteraan Hidup Masyarakat Sesuai Target SDG'S. Jurnal Pendidikan Luar Sekolah (PLS). Vol. 6(3): 304-309.

Permendikbud No. 65 Tahun 2013 Tentang Standar Proses Pendidikan Dasar dan Menengah. 2013. 
Jakarta: Kementerian Pendidikan dan Kebudayaan RI.

Putra, R. A., Kamil, M., Pramudia, J. R. 2017. Penerapan Metode Pembelajaran Mandiri dalam Meningkatkan Hasil Belajar Peserta Didik. Jurnal Pendidikan Luar Sekolah. Vol. 1(1): 23-36.

Sunarsi, D. 2018. Analisis Motivasi Kerja Tenaga Pendidik Sukarela pada Pusat Kegiatan Belajar Masyarakat (PKBM) Bimasda Kota Tangerang Selatan. Jurnal Kreatif: Pemasaran, Sumber Daya Manusia, dan Keuangan. Vol. 6(2): 53-65.

Susanto, E. dan Retnawati, H. 2016. Perangkat Pembelajaran Matematika Bercirikan PBL untuk Mengembangkan HOTS Siswa SMA. Jurnal Riset Pendidikan Matematika. Vol. 3(2): 189-197. 